\title{
Purification of bovine milk alkaline proteinase and comparison with purified bovine blood plasminogen or plasmin
}

\author{
G Humbert 1, A Berbar 1, G Godbillon 2, \\ JY Le Deaut 1, G Linden 1 \\ 1 Laboratoire de Biochimie Appliquée (associé à I'INRA), \\ 2 Université de Nancy I, Faculté des Sciences, Laboratoire de Biologie Animale, \\ BP 239, 54506 Vandceuvre-lès-Nancy, Cédex, France
}

(Received 29 January 1990; accepted 16 February 1990)

\begin{abstract}
Summary - The bovine blood plasminogen $(\mathrm{Plg})$ has been purified by affinity chromatography on Lysine-Sepharose. An electrophoresis pattern revealed some minor contaminant bands. The possibilities of contamination and activation of Plg have been examined; the likely causes of the heterogeneousness are:

1) an in vivo activation just before or during slaughter of the animals;

2) a partial activation during purification;

3) a self-activation or a self-hydrolyse which is a characteristic of proteinases or

4) a contamination of the chromatography column.

The milk alkaline proteinase was purified by affinity chromatographies on Lysine-Sepharose and an immunoadsorbant (rabbit anti-bovine plasminogen serum) from whole casein and on enzymeenriched fraction. The purified fractions were partially heterogeneous and presented some minor components which are plasmin-chains. This sustains the assumption that self-activation or activation caused by traces of a whey activator in the whole casein occur. Blood and milk purified fractions were compared (electrophoresis, double-immunodiffusion, glycoprotein staining). This paper presents a novel method to purify the milk alkaline proteinase and to confirm the similarities between blood- and milk proteinase.
\end{abstract}

milk alkaline proteinase / blood plasminogen or plasmin / purification / affinity chromatography / immunological reaction

Résumé - Purification de la protéase alcaline du lait et comparaison avec la plasmine ou le plasminogène sanguins bovins purifiés. Le plasminogène du sang bovin a été purifié par chromatographie d'affinité sur Lysine-Sepharose. II présente une bande majeure et des bandes mineures en électrophorèse et un arc contaminant en double immunodiffusion. Les possibilités de contamination ou d'activation du plasminogène sont examinées; ces causes d'hétérogénéité seraient:

1) une activation in vivo au moment du prélèvement du sang,

2) une activation partielle pendant la purification,

3) une autoactivation ou autolyse caractéristique des protéases, ou

4) une contamination du support chromatographique.

La chromatographie d'affinité sur Lysine-Sepharose et la chromatographie d'affinité sur immunoadsorbant (antisérum antiplasminogène bovin obtenu chez le lapin) ont été utilisées pour purifier la protéase alcaline du lait à partir de la caséine entière et d'une fraction protéique enrichie en enzyme. Les préparations sont hétérogènes en électrophorèse. En milieu dissociant, l'électrophorèse révèle des bandes mineures correspondant aux chaînes lourde et légère de la plasmine. Comme dans le cas du plasminogène sanguin il est permis de penser à une autoactivation, ou à une activation provoquée par des traces d'un activateur lactosérique dans la caséine. Les préparations contiennent 
donc du plasminogène et de la plasmine du lait ou apparue pendant le cycle de purification. Les enzymes du lait et du sang sont comparées par électrophorèses en gel de polyacrylamide et par immunodiffusion radiale. La protéase alcaline est, comme le plasminogène, une glycoprotéine. Ce travail présente donc une nouvelle voie de purification de la protéase alcaline du lait et montre de nouveau qu'elle est l'enzyme du sang.

protéase alcaline du lait bovin / plasminogène ou plasmine du sang / chromatographie d'affinité / électrophorèse / immunochimie

\section{INTRODUCTION}

Alkaline proteinase (MAP) is the major component of the milk endogenous proteinase system. The properties of this enzyme have been reviewed by Humbert and Alais (1979) and more recently Miranda and Gripon (1986); Grufferty and Fox (1988a). This proteinasic activity may affect various dairy products by modifying rheology properties (gelation of UHT milk, viscosity of custards), flavour properties (apparition of bitterness), or diminishing cheese yield.

The study of molecular and kinetic properties has shown that milk alkaline proteinase displays certain similarities to blood plasmin. Kaminogawa et al (1972) were the first workers to report an analogy between these 2 enzymes.

Many enzyme purification experiments have been conducted (Humbert and Alais, 1979) and different protocols or methods of purification have been compared (Von Halpaap et al, 1977; Reimerdes et al, 1981a; Manji and Kakuda, 1986). Some authors have examined the sensibility of these endopeptidases to different effectors (Kaminogawa et al, 1972; Hofmann et al, 1979; Reimerdes et al, 1981a,b; Rollema et al, 1981, 1983). Others have studied its specific effects on caseins (Snoeren and Van Riel, 1979; Aimutis and Eigel, 1982; de Rham and Andrews, 1982; Andrews and Alichanidis, 1983, etc).

In this paper, the purification of blood and milk enzymes by affinity chromatogra- phy on Lysine-Sepharose will be described. Milk alkaline proteinase was also purified by affinity chromatography on immunoadsorbant using an antiplasminogen serum. Finally the products obtained by these purifications will be compared. Figure 1 depicts the experimental proceedings.

\section{MATERIALS AND METHODS}

\section{Materials}

Sephadex G-25 Superfine, Agarose C and Lysine-Sepharose were from Pharmacia Fine Chemicals (Uppsala, Sweden). Activated Ultrogel ACA 22 was from IBF Pharmindustrie (Clichy, France). Acrylamide and Bis-acrylamide

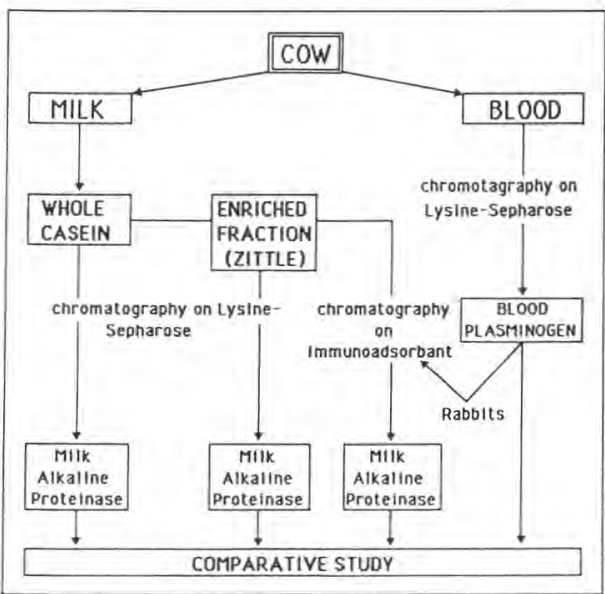

Fig 1. Experimental proceedings. Plan d'expérimentation. 
were from BDH (Poole, England). Urokinase (15 $000 \mathrm{UI} / \mathrm{ml}$ ) was from Choay (Paris, France). Freund complete adjuvant was from Gibco (New York, USA).

\section{Methods}

\section{Preparation of blood plasma}

The bovine blood is collected immediately after cutting the animal's throat. The blood is sampled in a receptable containing $0.13 \mathrm{~mol}^{-1}$ trisodium citrate and slightly stirred. The citrated blood (1 part of citrate solution +9 parts of blood) is centrifuged $(4000 \mathrm{~g}, 30 \mathrm{~min})$ at $5{ }^{\circ} \mathrm{C}$. The citrated plasma is again centrifuged at $3000 \mathrm{~g}, 10 \mathrm{~min}$ before being frozen.

\section{Purification of blood plasminogen (Plg)}

Plasminogen was purified from $500 \mathrm{ml}$ of citrated plasma by affinity chromatography on Lysine-Sepharose according to Deutsch and Mertz (1970). The chromatography was carried out at $5{ }^{\circ} \mathrm{C}$ on a $2.5 \times 15 \mathrm{~cm}$ column at a flow-rate of $75 \mathrm{ml}^{-1}$ in $0.05 \mathrm{~mol}^{-1} \mathrm{l}^{-1}$ Tris $/ 0.01 \mathrm{~mol}^{-1}$ $\mathrm{ZnSO}_{4} / 0.02 \% \quad \mathrm{NaN}_{3} \mathrm{pH} 8$ buffer. The nonadsorbed proteins were eluted with $0.5 \mathrm{~mol}^{-1}$ $\mathrm{NaCl}$ - Tris buffer, and then plasminogen was desorbed by 0.2 molel-1 $^{-1} \varepsilon$ aminocaproic acid Tris buffer. Finally the gel is washed with 6 molol-1 urea - Tris buffer before equilibrated in original Tris buffer. All the buffers of the affinity step contained $0.001 \mathrm{~mol}^{-1}$ Zinc sulphate to prevent the plasminogen activation (Dano and Reich, 1979).

The $\varepsilon$-aminocaproic acid was then eliminated at $5{ }^{\circ} \mathrm{C}$ by chromatography of obtained proteinous fraction on $5 \times 100 \mathrm{~cm}$ Sephadex G-25 column in $0.01 \mathrm{~mol}^{-1} \mathrm{~T}$ Tris $/ 0.02 \% \mathrm{NaN}_{3} \mathrm{pH} 8$ buffer at a flow rate of $70 \mathrm{~mol}^{-1}$.

\section{Antibody production}

The antibody to plasminogen was obtained intravenously and subcutaneously injecting rabbits with $5.5 \mathrm{mg}$ of plasminogen dissolved in $1.5 \mathrm{ml}$ of a 1/1 mixture of physiological saline and Freund's adjuvant. Four intravenous shots (2.5 $\left.\mathrm{mg} . \mathrm{l}^{-1} / \mathrm{rabbit}\right)$ were given after $24,31,48$ and 59 d. Blood was retrieved $6 \mathrm{~d}$ after the last injection.

Isolation of IgG was accomplished by a classical treatment of the blood serum by 3 $\left(\mathrm{NH}_{4}\right)_{2} \mathrm{SO}_{4}$ precipitations. The IgG were then dissolved in 0.1 mol. - $^{-1} \mathrm{Na}_{2} \mathrm{HPO}_{4} / 0.15$ mol. - $^{-1}$ $\mathrm{NaCl}$ buffer at $\mathrm{pH}$ 7.5. The antibody solution thus obtained was then used for affinity chromatography and for immunological analyse. Immuno-double diffusion according to Ouchterlony (1949) was used to test antigenic properties.

\section{Obtention of the milk alkaline proteinase-enriched fraction}

The freshly drawn milk was skimmed by centrifugation, and the whole casein was prepared using acid precipitation according to Nitschman and Lehman (1947). The different steps are specified in figure 2. The enriched-fraction (FZ) was prepared according to Zittle (1965) by acidificaton of casein to $\mathrm{pH} 3.5$ with $7 \mathrm{~N} \mathrm{H}_{2} \mathrm{SO}_{4}$, $\left(\mathrm{NH}_{4}\right)_{2} \mathrm{SO}_{4}$ precipitation and freeze-drying.

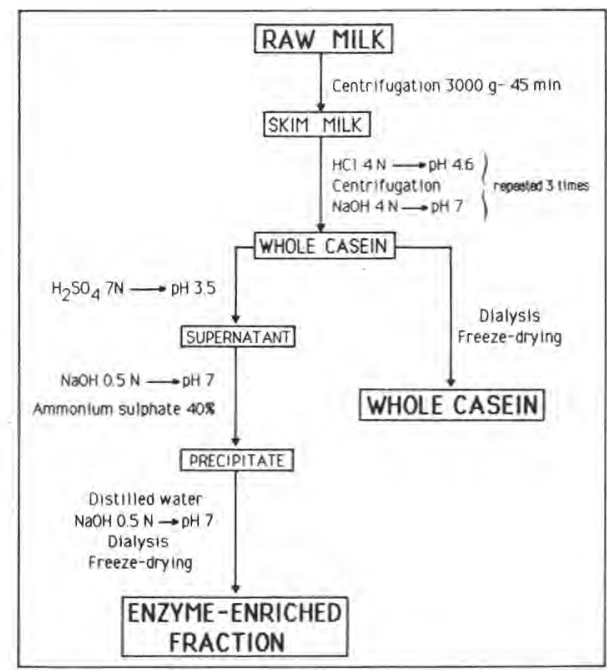

Fig 2. Procedure of preparation of whole casein and MAP-Enriched Fraction (FZ).

Préparation de la caséine entière et de la fraction (FZ) enrichie en protéase alcaline du lait. 


\section{Purificaton of milk alkaline proteinase (MAP)}

\section{Affinity chromatography on Lysine-Sepharose}

It was purified at $5{ }^{\circ} \mathrm{C}$ from whole casein or enzyme-enriched fraction according to Deutsch and Mertz (1970) on a $1.5 \times 5 \mathrm{~cm}$ column. After loading of $50 \mathrm{mg}$ of protein in $2 \mathrm{ml}$ of 0.05 mol.t-1 Tris/0.001 mol..$^{-1}$ Znso, $/ 0.14$ mol. I $^{-1}$ $\mathrm{NaCl} / 0.02 \% \mathrm{NaN}_{3} / \mathrm{pH} 8$ buffer the elution was stopped to facilitate the affinity linkings in the gel. Then the elution was continued at $50 \mathrm{ml}^{-\mathrm{h}^{-1}}$ with the same Tris buffer. The non-absorbed protein were eliminated by washing at $15 \mathrm{ml}^{-\mathrm{h}^{-1}}$ with 0.4 mol..$^{-1} \mathrm{NaCl}$-Tris buffer. Milk alkaline proteinase was desorbed with $0.1 \mathrm{~mol}^{-1}$ lysine $\mathrm{pH} 8$ solution at a flow-rate of $50 \mathrm{ml}$. $\mathrm{h}^{-1}$. Finally, the gel was washed with $6 \mathrm{~mol}^{-1} \mathrm{f}^{-1}$ urea which desorbes proteinous substances.

\section{Immunoaffinity chromatography}

The slurry of activated Ultrogel ACA 22 was washed successively with $0.5 \mathrm{~mol} \cdot \mathrm{I}^{-1}$, then 0.1 molot-1 sodium phosphate buffer $\mathrm{pH} 7.5$ containing $0.15 \mathrm{~mol}^{-1} \mathrm{l}^{-1}$ sodium chloride. The ligand, antibody to plasminogen was fixed onto the matrix during $18 \mathrm{~h}$ at $4^{\circ} \mathrm{C}$ while being stirred. Then the slurry was washed with the last buffer, the proportion of proteins not bound was evaluated in the eluate, measuring absorbance at $280 \mathrm{~nm}$. The coupling yield was about $60 \%$. The mixture gel-ligand was poured into the $(1.5 \times 5 \mathrm{~cm})$ column and washed with the same buffer.

Three $\mathrm{ml}$ of $\mathrm{FZ}$ proteins solution (10-30 $\mathrm{mg} \cdot \mathrm{ml}^{-1}$ ), previously equilibrated in the 0.1 mol.1 ${ }^{-1} \mathrm{KH}_{2} \mathrm{PO}_{4} / 0.15$ mol.t-1 $\mathrm{NaCl} / 0.02 \% \mathrm{NaN}_{3}$ $\mathrm{pH} 7$ buffer, were loaded onto the column at room temperature. After a first washing step at the flow-rate of $10 \mathrm{ml} \mathrm{h}^{-1}$ with $0.2 \mathrm{~mol} \cdot \mathrm{l}^{-1} \mathrm{gly}$ cine/0.15 molel-1 NaCl pH 2.4 buffer at 55 $\mathrm{ml}^{\circ} \mathrm{h}^{-1}$, dropped into tubes previously filled with 1 molol-1 $^{-1}$ potassium phosphate buffer $\mathrm{pH} 8$ and stirred. The proteins were rapidly dialyzed and frozen. After chromatography the gel was washed with $10 \%$ dioxan at a flow-rate of 55 $\mathrm{ml}^{\circ} \mathrm{h}^{-1}$ before equilibrating in the phosphate buffer.

\section{Electrophoresis}

Polyacrylamide gel electrophoresis (PAGE) and sodium dodecyl sulphate polyacrylamide gel electrophoresis (SDS-PAGE) on vertical gel slabs were carried out according to Hillier (1976) and Laemmli and Favre (1973) respectively. Gels were also specifically stained with Fuchsine according to Kapitany and Zebrowski (1973) to detect glycoproteins.

\section{Detection of endopeptidasic activity}

Detection occurred at $37^{\circ} \mathrm{C}$ in Petri dishes using a method similar to that reported by Laurence and Sanderson (1969). The mixture consisted of gelose (1.5\%) and reconstituted-milk $(30 \%)$, in a Tris/ $\mathrm{HCl}$ buffer $\left(0.05 \mathrm{~mol}^{-1} ; \mathrm{pH} 7.5\right)$ containing $0.01 \%$ merthiolate. A $10 \mathrm{ml}$ aliquot of agar mixture was poured into the dish on a level table. After cooling at room temperature $3 \mathrm{~mm}$ diameter wells were punched in the agar gel and filled with $10 \mu$ of protein samples.

\section{Activation of plasminogen by urokinase (UK)}

Activation was sustained for $20 \mathrm{~min}$ at $37^{\circ} \mathrm{C}$. The reaction mixture contained $100 \mu \mathrm{l}$ of urokinase $(750 \mathrm{UI}=525$ Plough $)$ and $50 \mu \mathrm{l}$ of proenzymatic fraction solution (10 $\mu \mathrm{g}$ of protein). UK-activated $\mathrm{Plg}$ is plasmin (PIm).

\section{Abreviations for plasminogen and plasmin molecules}

We shall use the abreviations according to the common nomenclature: for instance $\mathrm{Glu}_{1}-\mathrm{Plg}$ for Glutamic $_{1}$-Plasminogen, Lys ${ }_{77}-\mathrm{Plg}$ for Lysin $\Theta_{77^{-}}$ Plasminogen. The indicated amino acid corresponds to the $\mathrm{NH}_{2}$-terminal residue, and the number to its position in the primary sequence of plasminogen.

\section{RESULTS}

\section{Characteristics of purified blood plasminogen}

The plasminogen obtained by chromatography on Lysine-Sepharose presents on 
PAGE pattern major bands with feeble mobility (fig $3 A$, slot a). A sample of plasminogen previously activated by UK results in a much more complex pattern (fig $3 \mathrm{~A}$, slots $\mathrm{b}$ and $\mathrm{c}$ ).

In SDS-PAGE, the plasminogen (fig 3B, slot a) shows several bands: a major band of protein with weak mobility and a molecular weight greater than $90 \mathrm{kDa}$ and, minor bands with higher mobility, 1 of which corresponds to $60 \mathrm{kDa}$. By activating the plasminogen with UK, the $90 \mathrm{kDa}$ band disappears as 2 major bands ( $60 \mathrm{kDa}$ and 25 $\mathrm{kDa}$ ) appear progressively (fig 3B, slot b).

In immunodouble diffusion, Plg shows 2 arcs against anti-serum (fig 4A). The internal arc, corresponds to the precipitin reaction between Plg and its antibody, the external to the precipitin reaction between bovine immunoglobulins and antiserum. This contaminant arc is also present when the reaction of diluted milk to antiserum is tested (fig 4B, 4C). Whole casein, B- lactoglobulin and serumalbumine give no precipitin reaction. When Plg and PIm obtained with UK are tested, the contaminant arcs are in continuity with those formed between antiserum and bovine immunoglobulin. The continuity of the principal arcs of $\mathrm{Plg}$ and PIm, points to a partial identity (fig 4D). Antigenic determinants are localized on the $\mathrm{NH}_{2}$-terminal peptide of Plg (1-76) which is eliminated by activation with UK. No precipitin reaction occurs between antiserum and UK.

\section{Comparative study of purified fractions (PIg and MAP)}

\section{Electrophoretic behaviour}

The 2 milk enzymatic fractions obtained by the 2 ways of chromatography on LysineSepharose and on immunoadsorbant do not present PAGE patterns similar to that of blood Plg (fig 5A). The former show, as $\mathrm{PIm}$, quicker bands (relative mobility =

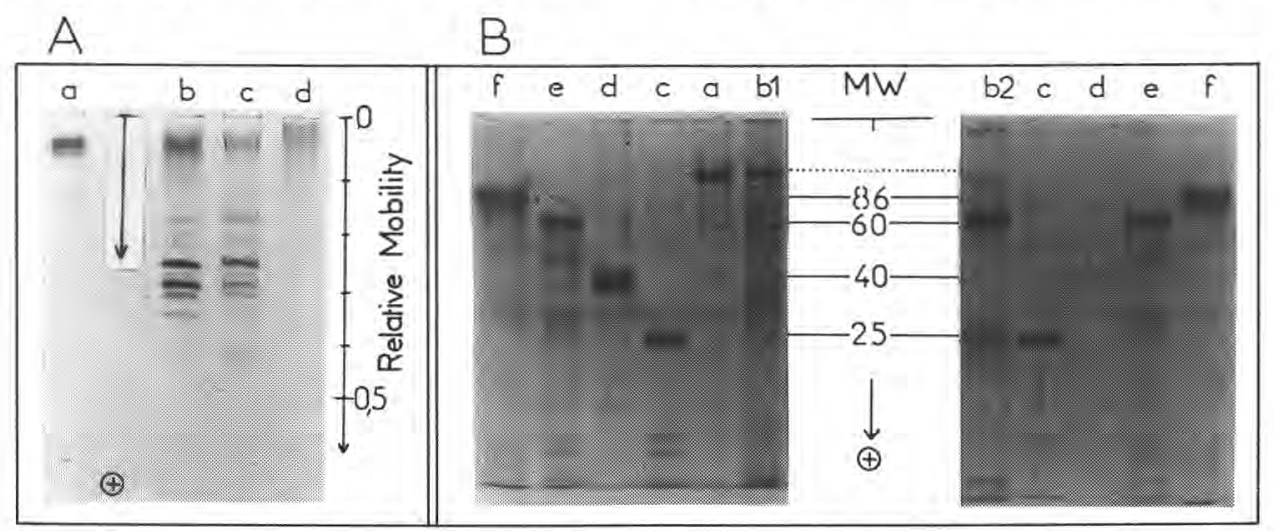

Fig 3. Electrophoretic study of blood enzyme. A PAGE pattern of blood Plg (a), of activated Plg (b, c) and of UK (d). B SDS-PAGE pattern of blood Plg (a), of little activated Plg $\left(\mathrm{b}_{1}\right)$ and of total activated $\mathrm{Plg}\left(\mathrm{b}_{2}\right)$. Standard Proteins: chymotrypsinogen (c), aldolase (d), catalase (e) and bovine transferrin (f). Molecular weights in $\mathrm{kDa}$.

Etude électrophorétique de l'enzyme du sang. A En gel natif : plasminogène sanguin purifié (a), activé en plasmine $(b, c)$ et urokinase $(d)$. B En milieu dissociant (SDS + mercaptoéthanol) : plasminogène sanguin purifié (a), partiellement $\left(b_{1}\right)$ et totalement activé $\left(b_{2}\right)$ en plasmine. Protéines étalons : chymotrypsinogène (c), aldolase (d), catalase (e) et transferrine bovine ( $f$. Les poids moléculaires sont exprimés en $k D a$. 


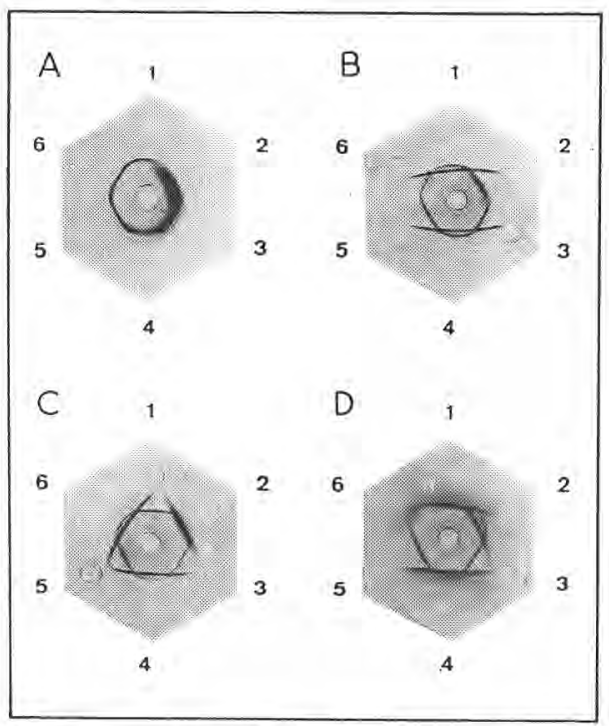

Fig 4. Immunodouble diffusion patterns demonstrating the presence of a contaminant protein in antigenic Plg preparation (A, B), in dialysed milk (C) and in Plm (D). Center wells contain anti-Plg serum; A 1-6 : dilution 1/1 to $1 / 32$ of blood Plg $8.5 \mathrm{mg}^{-\mathrm{ml}^{-1}}$; B 1,4: Plg (1 mg.ml-1); 2,5 : immunoglobulin $\left(1\right.$ and $\left.0.5 \mathrm{mg}^{-1} \mathrm{ml}^{-1}\right) ; 3.6$ : dilution $1 / 2,1 / 4$ of dialysed milk; $C 1,3,5$ : dilutions $1 / 1,1 / 2$ and $1 / 4$ of dialysed milk; 2,4,6: blood Plg (1, 0.5 and $0.25 \mathrm{mg} \cdot \mathrm{ml}^{-1}$ ); D 1,4: blood Plg ( $\left.0.5 \mathrm{mg}^{\mathrm{ml}} \mathrm{I}^{-1}\right)$; 2: PIm; 3,5: immunoglobulins $\left(0.5 \mathrm{mg} \cdot \mathrm{ml}^{-1}\right)$.

Mise en évidence par double immunodiffusion de la présence d'un contaminant protéique dans la préparation antigénique de plasminogène (A, B), dans le lait dialysé (C) et dans la plasmine (D). Les puits centraux contiennent le sérum anti-plasminogène. A 1-6: dilutions 1/1 à 1/32 du plasminogène sanguin $\left(8,5 \mathrm{mg}^{\mathrm{ml}} \mathrm{H}^{-1}\right) ; B$ 1,4 : plasminogène sanguin $\left(1 \mathrm{mg} \cdot \mathrm{ml}^{-1}\right) ; 2,5$ : immunoglobulines (1 et $0,5 \mathrm{mg} \cdot \mathrm{mr}^{-1}$ ); 3,6 : dilutions 1/2 et $1 / 4$ du lait dialysé; $C 1,3,5$ : dilutions $1 / 1,1 / 2$ et $1 / 4$ du lait dialysé; $2,4,6$ : plasminogène sanguin $\left(1,0,5\right.$ et $\left.0,25 \mathrm{mg}^{\mathrm{ml}} \mathrm{I}^{-1}\right) ; D^{1,4}$ : plasminogène sanguin $\left(0,5 \mathrm{mg} \cdot \mathrm{ml}^{-1}\right) ; 2$ : plasmine; 3,5: immunoglobulines $\left(0,5 \mathrm{mg} \cdot \mathrm{ml}^{-1}\right)$.

$R M=0.30,0.34$ and $0.08-0.12$, the last one being large). The 2 fractions have the same patterns but those obtained by immunochromatography display a more pronounced and quicker band $(R M=0.60)$ as well as minor bands $(R M=0.74,0.85)$ with equally higher velocities.

In SDS-PAGE (fig 5B-CS) the enzymatic fraction obtained from casein by affinity on Lysine-Sepharose (slot b) shows a band which is slightly ahead of Plg (slot a) and minor rapid bands which are also present in Plg. The enzymatic fraction obtained from $\mathrm{FZ}$ by immunoadsorbant consists of a principal band $(R M=0.16)$ and a faint doublet corresponding to the 2 glycosyled Plg variants. Fuchsine staining shows Plg and the milk enzymatic preparation to be glycoproteins (fig 5B-FS). Most plasmin bands ( $R M=0.1-0.3$, on slot $\mathrm{d}$ on fig 5B-FS) also contain carbohydrates.

\section{Endopeptidasic activity}

The 2 enzymatic fractions obtained from FZ by chromatography on LysineSepharose and on immunoadsorbant produce a proteolytic area in agar-milk plate. Plg and milk enzymes obtained on LysineSepharose show no detectable activity after a $24 \mathrm{~h}$ incubation period. All the tested preparations but not UK itself reveal caseolytic activity after UK-activation.

\section{Immunological relationships}

In immunodouble diffusion, 3 preparations obtained from FZ by affinity on immunoadsorbant show precipitin reactions (fig $6 A, B, C)$ with 2 arcs. The first arc is in continuity with the principal one of PIm but not with those of Plg. The second is in continuity with that formed by the contaminant of Plg or PIm.

Preparation number 2 shows a third internal arc, which is in partial continuity with principal arc of Plg and PIm (fig 6B).

Milk enzyme obtained from whole casein by chromatography on LysineSepharose gives a preciptin arc in conti- 


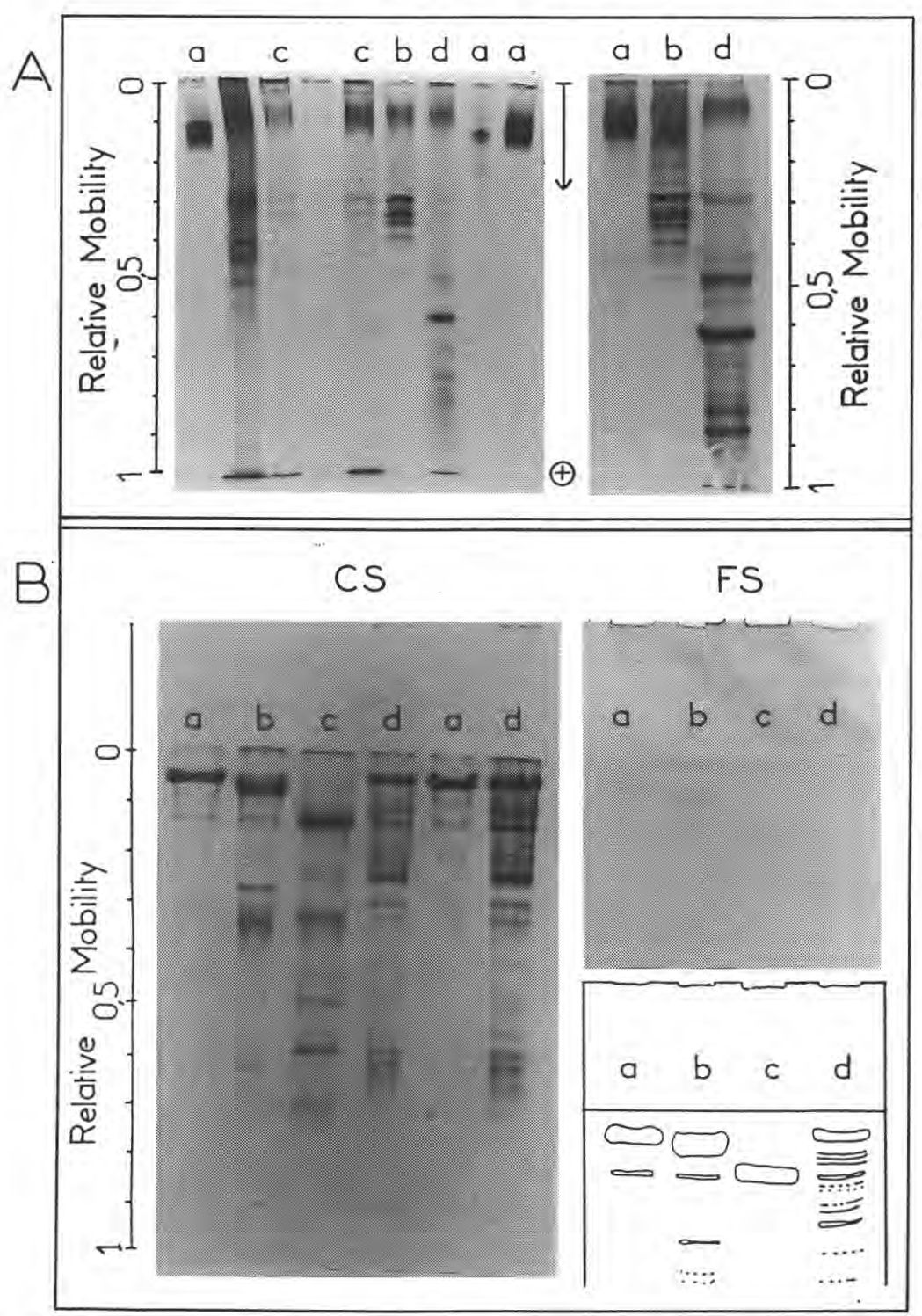

Fig 5. Electrophoretic study of milk enzyme. A : Comparative PAGE patterns of blood Plg (a), of UKactivated Plg (b), of MAP obtained from FZ by affinity chromatographies on Lysine-Sepharose (c) and on immunoadsorbant (d). B : Comparative SDS-PAGE patterns with Coomassie (CS) or Fuchsine (FS) staining of blood Plg (a), of MAP obtained from casein by chromatography on Lysine-Sepharose (b), of MAP obtained from FZ by chromatography on immunoadsorbant (c) and of UK-activated Plg (d).

Etude électrophorétique de l'enzyme du lait. A : Comparaison en gel natif du plasminogène sanguin (a), du plasminogène activé par l'urokinase (b), de la protéase alcaline du lait obtenue à partir de la fraction enrichie FZ par chromatographie d'affinité sur Lysine-Sépharose (c) et sur immunoadsorbant (d). B : Comparaison en milieu dissociant après coloration au bleu de Coomassie (CS) ou à la Fuchsine (FS) du plasminogène sanguin (a), de la protéase alcaline du lait obtenue par chromatographie sur Lysine-Sepharose à partir de la caséine entière (b), ou par chromatographie sur immunoadsorbant à partir de la fraction FZ (c) et du plasminogène activé par l'urokinase (d). 


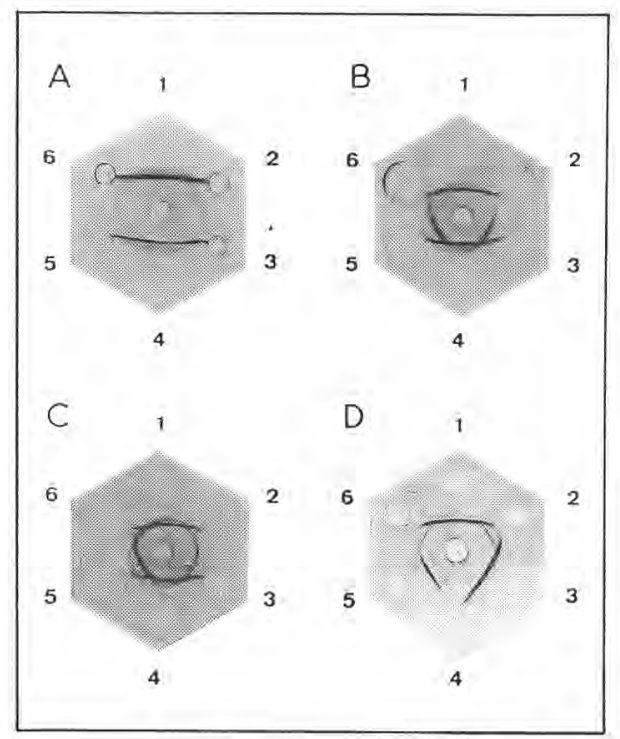

Fig 6. Immunodouble diffusion patterns resulting from the interaction of anti-Plg serum (center wells) and the different MAP preparations obtained from $F Z$ by chromatography on immunoadsorbant (A, B, C) and from whole casein by chromatography on Lysine-Sepharose (D). A : 1,4: Plg (0.5 mg.ml-1); 2,5: MAP preparation no 1 diluted $1 / 1$ and $1 / 2 ; 3,6$ : MAP preparation no 2 diluted $1 / 2$ and $1 / ; B: 1,4 \mathrm{Plg}(0.5$ mg. $\mathrm{ml}^{-1}$ ); 2,6: MAP preparation no 2, dilution 1/ 1 ; 3 : immunoglobulin $\left(0.25 \mathrm{mg}^{-1} \mathrm{ml}^{-1}\right)$; 5 : UKactivated $\mathrm{Plg} ; \mathrm{C}: \mathrm{B}$ with MAP preparation no 3 , dilution $1 / 1 ; D: 1,3$ : Plg (0.5 mg.ml-1); 2,6 MAP; 5 : immunoglobulins $\left(0.5 \mathrm{mg}^{\mathrm{ml}} \mathrm{m}^{-1}\right)$.

Mise en évidence par double immunodiffusion de la réaction entre le sérum anti-plasminogène (puits centraux) et les différents lots de protéase alcaline du lait (MAP) obtenus à partir de la fraction FZ par chromatographie sur immunoadsorbant $(\mathbf{A}, \mathbf{B}, \mathbf{C})$ et à partir de la caséine par chromatographie sur Lysine-Sepharose (D). A : 1,4 : plasminogène sanguin $\left(0,5 \mathrm{mg}^{\circ} \mathrm{ml}^{-1}\right) ; 2,5:$ lot de MAP $n^{\circ} 1$, dilution $1 / 1$ and 1/2; 3,6:lot de MAP $n^{\circ} 2$, dilution $1 / 2$ and $1 / 1 ; B: 1,4$ : plasminogène sanguin $\left(0,5 \mathrm{mg} \cdot \mathrm{ml}^{-1}\right) ; 2,6:$ lot de MAP $n^{\circ} 2$, dilution $1 / 1 ; 3$ : immunoglobulines $(0,25$ $\mathrm{mg} \cdot \mathrm{ml}^{-1}$ ); 5 : plasminogène activé par l'urokinase; $C: B$ avec le lot de MAP $n^{\circ} 3$, dilution $1 / 1$; $D: 1,3$ : plasminogène sanguin $\left(0,5 \mathrm{mg} \cdot \mathrm{ml}^{-1}\right)$; 2,6: MAP; 5 : immunglobulines $\left(0,5 \mathrm{mg}^{\circ} \mathrm{ml}^{-1}\right)$. nuity with Plg (fig 6D). Contaminant is also present.

\section{DISCUSSION}

\section{Problems linked to blood plasminogen purification}

The concentration of $\varepsilon A C A$ used $(0.2$ mol. $\left.\right|^{-1}$ ) is higher than those used by many authors for the purification of different mammalian blood plasminogens (dog, rabbit, goat, sheep...); eg Brockway and Castellino (1972) have separated the 2 glycosyled variants of human $\mathrm{Plg}$ using an EACA-gradient 0.007 to $0.02 \mathrm{~mol}^{-1} \mathrm{I}^{-1}$. The high concentration of EACA solution does not prevent the proteinous contamination of the column by fibrinogen when chromatographies are repeated. To dissolve this fibrinous deposit, Hatton and Regoeczi (1974) used $0.2 \mathrm{~mol}^{-1} \mathrm{I}^{-1}$ Lysine. In the present work a 6 mol. I-1 $^{-1}$ urea solution was used.

It is necessary to eliminate EACA of Plgpreparation by gel filtration as this acid is a plasmin inhibitor as well as a competitive inhibitor of urokinase and streptokinase for the activation of the proenzyme (Ablondi et al, 1959; Castellino, 1981). Gel filtration chromatography is more rapid than dialysis.

PAGE reveals minor bands which are certainly Plg-degradation products. In SDS-PAGE there are not 2 bands corresponding to the 2 glycosyled forms of bovine Plg (Schaller et al, 1985) but several small bands with higher mobilities. Several explanations may be proposed:

- A partial activation of Plg occurs during gel filtration steps; yielding a mixture of $\mathrm{Plg}+\mathrm{Lys}$ - Plg (86 kDa) + H-chain (60 $\mathrm{kDa})$ and L-chain (25 kDa) of Plm. By 
chromatography on Lysine-Sepharose and Lysine or Arginine gradients, Radcliffe and Heinze (1978) have purified a human Plg activator. $\varepsilon A C A$ may also elute an activator which hydrolyses PIg during experimental steps, in which case the preparation is heterogenous.

- In neutral solution serine-proteinases often hydrolyse themselves (Walsh and Wilcox, 1970).

- The contamination occurs during the Plg-preparation. According to Thorsen (1975), the degraded forms of Plg, bearing a strong affinity to fibrin, can carry fibrin or fragments of fibrin. Thus, Maillard and Favreau (1977) have observed with immunoelectrophoresis that mouse Plg purified by chromatography on Lysine-Sepharose contains traces of $\alpha$ - and $\gamma$-globulins. Hatton and Regoeczi (1974) have observed that Lysine-Sepharose retains IgG molecules desorbed with 0.2 mol. $1^{-1}$ Lysine. The present work reports on the contamination by $\gamma$-globulin through immuno double diffusion. Connell and Porter (1971) have demonstrated that rabbit plasmin hydrolyses immunoglobulins, hence traces of plasmin in the preparation may retain very small quantities of substrate.

- Activation of Plg occurs just before or during slaughter of the animals. Yamamoto et al $(1982,1983)$ have shown that human plasma contains $78.5 \%$ native $\mathrm{Plg}, 15.5 \%$ $\mathrm{PIm}$ and $6.1 \%$ modified forms (ie $\mathrm{Lys}_{77}$ $\mathrm{Plg}$ ). The proportion of modified forms increases $(50 \%)$ after strenuous exercise. Yamamoto et al (1984) reported that Lys $_{77}$ Plg constituted the major part of modified forms and that their half-life fell within the range of 5-30 min. Wiman et al (1983) reported a half-life of $5 \mathrm{~min}$. Mc Nicol and Douglas (1972) announced the activator role of "stress" in human blood. The "stress" and strenuous exercise of cows before slaughter, have been evidenced. There is reason to assume that their physiological state is akin to that reported by Yamamoto et al (1982, 1983, 1984).

\section{Purification of MAP and comparisons with Plg}

MAP being associated with casein (Eigel et al, 1979), may also be found in the fat globule membrane (Hofmann et al, 1979). According to Slattery (1976) or Schmidt (1980) casein Kappa is abundantly present in the superficial layer of the micelle. Although being subject to controversy (Humbert and Alais, 1979) MAP could be associated to the casein Kappa. Nevertheless, most authors use the method of Zittle (1965) in the initial step of MAP purification, with acidification to $\mathrm{pH} 3.5$ (Humbert and Alais, 1979). Von Halpaap et al (1977) acidified the micellar casein to $\mathrm{pH} 2.0$. Grufferty and Fox (1988b) have shown the necessity of $\mathrm{pH}$ being inferior to 4.6 in order to desorb Plg from the micellar complex.

The elution profiles of affinity chromatography on Lysine-Sepharose were identical when loads were ivhole casein or FZ. It was necessary to stagnate elution during $1 \mathrm{~h}$ when loads descended into the column, to permit affinity fixation on the ligand. The elution of adsorbed proteins was brought about using $0.1 \mathrm{~mol}^{\circ} \mathrm{l}^{-1}$ Lysine because 0.2 mol.1-1 $^{-1}$ EACA was not efficient. During the chromatography on immunoadsorbant, Glycine does not totally elute proteinous substances; the residual proteinous substance adsorbed on the gel, not eluted by 0.2 molol-1 Glycine is desorbed by $10 \%$ dioxanne or equilibrating in phosphate buffer.

PAGE shows that the milk enzyme preparations are different from $\mathrm{Plg}$ but bear a resemblance to activatedplasminogen. On the SDS-PAGE pattern, the enzyme obtained from whole casein by 
chromatography on Lysine-Sepharose has a slightly higher mobility than $\mathrm{Plg}$ (Asp $\mathrm{P}_{1}$ $\mathrm{Plg}$ ) and is, in fact, $\mathrm{Lys}_{77}-\mathrm{Plg}$. The FZbased enzyme, purified on immunoadsorbant has electrophoretic patterns different from those obtained with $\mathrm{Plg}$ or casein (fig 7). This preparation is slightly degraded, perhaps due to the acid elution $(\mathrm{pH}$ 2.3). It is better to use distilled water (Bureau and Daussan, 1981) or preferably neutral solutions with chaotropic ions.

Furthermore, a different pattern emerges with enzyme obtained from FZ on Lysine-Sepharose (fig 7, slot c): there is a doublet of $\mathrm{H}$-chains which corresponds to the 2 glycosyled variants.

The 2 preparations purified from FZ contain proteins with molecular weights of 60 and $25 \mathrm{kDa}$. They are plasmin mole- cules because they also display endopeptidasic activity without UK-activation. Therefore plasmin was prepared instead of plasminogen. The acid elution proved, then, not to be solely responsible for this activation.

Zittle's method may be assumed to cause an activation of $\mathrm{Plg}$ or to allow this activation by an endogenous activator. The possible existence of small quantities of the whey Plg-activator (Korycka-Dahl et al, 1983) in our casein and our fraction (FZ) should not be excluded.

Manji and Kakuda (1986) have shown that the enzymatic preparation obtained by chromatography of casein on LysineSepharose consists of $90 \% \mathrm{Plg}$ and $10 \%$ $\mathrm{PIm}$, indicating the possibility of selfactivation.

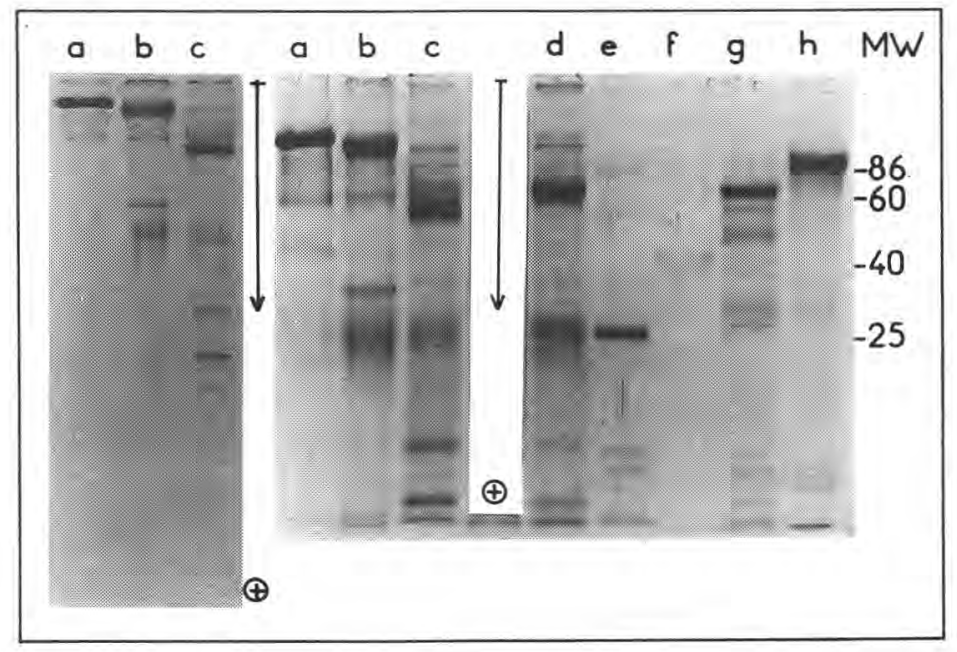

Fig 7. SDS-PAGE patterns of enzymatic preparations obtained by affinity chromatography on LysineSepharose from blood $(\mathrm{a}=\mathrm{Plg}$ ), from whole casein (b) and from FZ (c). Slot (d) is UK-activated Plg. Standard proteins: chymotrypsinogen (e), aldolase $(\mathrm{f})$, catalase $(\mathrm{g})$ and bovine transferrin $(\mathrm{h})$. Molecular weights in $\mathrm{kDa}$.

Electrophorégramme en milieu dissociant (SDS + mercaptoéthanol) des préparations enzymatiques obtenues par chromatographie d'affinité sur Lysine-Sepharose à partir du sang (a), ou de la caséine entière (b) ou de la fraction enrichie $F Z$ (c). Dépôt (d) : plasminogène sanguin activé par l'urokinase. Protéines étalons : chymotrypsinogène $(e)$, aldolase $(f)$, catalase $(g)$ et transferrine bovine $(h)$. Les poids moléculaires sont exprimés en $k D a$. 
Immunodouble diffusion tests show that prepared milk alkaline proteinases are $\mathrm{Plg}$, and sometimes PIm. In the latter case, there was an activation during experimental steps. Moreover, this technique detects immunoglobulins in antigenic solutions and consequently their antibodies in antiserum. In milk, immunoglobulins are localised in whey, but traces then remain in washed isoelectric casein.

There are different precipitin reactions with milk alkaline proteinase obtained from FZ. The third arc obtained in 1 preparation is reminiscent of the works of Eigel et al (1979) and Hofmann et al (1979) who reported 2 arcs between antiplasminogen serum and whole casein or fat globule membrane. They attributed these precipitin arcs to different concentrations of Plg, PIm and other modified forms with lower molecular weights. The antigenic solution may contain $\mathrm{Asp}_{1}$, Lys $77, \mathrm{Val}_{354}, \mathrm{Val}_{442}, \ldots \mathrm{Plg}$ or PIm, hence the antibodies obtained may cover a wide range. This problem may certainly be resolved using monoclonal antibodies.

\section{CONCLUSION}

In conclusion, milk alkaline proteinase was purified using a novel method (affinity chromatography on immunoadsorbant) and a more conventional one (affinity chromatography on Lysine-Sepharose). Today, only 1 and hardly satisfying discelectrophoresis pattern has been reported (Kaminogawa et al, 1971) but the vertical gel slab electrophoresis is more reliable and our obtained patterns are also better. In the present study, the electrophoretic patterns and the immunological relationships confirm that milk alkaline proteinase is identical to blood plasminogen (or plasmin). This paper reports a novel method to demonstrate the similarities between milk and blood proteins.

\section{ACKNOWLEDGMENTS}

The authors gratefully acknowledge C Tankosic for her technical assistance.

\section{REFERENCES}

Ablondi FB, Hagan JJ, Philips M, de Renzo EC (1959) Inhibition of plasmin, trypsin and the streptokinase activated fibrinolytic system by E aminocaproic acid. Arch Biochem Biophys 82, 153-160

Aimutis WR, Eigel WN (1982) Identification of $\lambda$ casein as plasmin-derived fragments of bovine $\alpha_{s 1}$-casein. J Dairy Sci 65, 175-181

Andrews AT, Alichanidis E (1983) Proteolysis of caseins and the proteose-peptone fraction of bovine milk. J Dairy Res 50, 275-290

Brockway WJ, Castellino FJ (1972) Measurement of the binding of antifibrinolytic amino acids to various plasminogens. Arch Biochem Biophys 151, 194-199

Bureau D, Daussan J (1981) Immuno affinity chromatography of proteins. A gentle and simple desorption procedure. $J$ Immunol Methods 41, 387-392

Castellino FJ (1981) Recent advances in the chemistry of the fibrinolytic system. Chem Rev 81, 431-446

Connell GE, Porter RR (1971) A new enzymic fragment (Facb) of rabbit immunoglobin. Biochem J 124, 53

Dano K, Reich E (1979) Plasminogen activator from cells transíormed by an oncogenic virus. Biochim Biophys Acta 566, 138-151

Deutsch DG, Mertz ET (1970) Plasminogen: purification from human plasma by affinity chromatography. Science 170, 1095-1096

Eigel WN, Hofmann CJ, Chibber BAK, Tomich JM, Keenan TW, Mertz ET (1979) Plasminmediated proteolysis of casein in bovine milk. Proc Natl Acad Sci USA 76, 2244-2248

Grufferty MB, Fox PF (1988a) Milk alkaline proteinase. J Dairy Res 55, 609-630

Grufferty MB, Fox PF (1988b) Factors affecting the release of plasmin activity from casein micelles. NZJ Dairy Sci Technol 23, 153-163 
Von Halpaap I, Reimerdes EH, Klostermeyer H (1977) Milchproteinasen. VI. Vergleichende Isolierung von Plasminogen aus Rinderblut und einer Proteinase aus Kuhmilch. Milchwissenschaft 32, 341-346

Hatton MCW, Regoeczi E (1974) Some observations on the affinity chromatography of rabbit plasminogen. Biochim Biophys Acta 359, 55-65

Hillier RM (1976) The quantitative measurement of whey proteins using polyacrylamide-gel electrophoresis. J Dairy Res 43, 259-265

Hofmann CJ, Keenan TW, Eigel WN (1979) Association of plasminogen with bovine milk fat globule membrane. Int J Biochem 10, 909917

Humbert G, Alais C (1979) Review of the progress of Dairy Science: the milk proteinase system. J Dairy Res 46, 559-571

Kaminogawa S, Sato F, Yamauchi K (1971) Purification and some properties of milk protease. Agric Biol Chem 35, 1465-1467

Kaminogawa S, Mizobuchi $\mathrm{H}$, Yamauchi $\mathrm{K}$ (1972) Comparison of bovine milk protease with plasmin. Agric Biol Chem 36, 2163-2167

Kapitany RA, Zebrowski EJ (1973) A high resolution PAS stain for polyacrylamide gel electrophoresis. Anal Biochem 56, 361-369

Korycka-Dahl M, Ribadeau-Dumas B, Chene N, Martal J (1983) Plasmin activity in milk. J Dairy Sci 66, 704-711

Laemmli WK, Favre M (1973) Maturation of the head of bacteriophage T4. I: DNA packaging events. J Mol Biol 80, 575-599

Laurence RC, Sanderson WB (1969) A micromethod for the quantitative determination of rennets and other proteolytic enzymes. $J$ Dairy Res 36, 21-29

Maillard J, Favreau C (1977) Role immunitaire de la plasmine. I. Les cellules lymphoïdes convertissent le plasminogène en plasmine. Ann Immunol (Inst Pasteur) 128C, 985-997

Manji B, Kakuda Y (1986) Isolation and characterization of alkaline milk proteinase from raw bovine milk. J Dairy Sci 69 (suppl) 1, 71 (abstract D64)

Mc Nicol GP, Douglas AS (1972) The fibrinolytic enzyme system. In: Human Blood, Haemostatis and Thrombosis (Biggs R, ed) Blackwell Sci Publ Oxford, 361-394
Miranda G, Gripon JC (1986) Origine, nature et incidences technologiques de la protéolyse dans le lait. Lait 66, 1-18

Nitschmann HS, Lehmann W (1947) Zur Problem der Labwirkung auf Casein. Helv Chim Acta 30, 804-808

Ouchterlony O (1949) Antigen-antibody reaction in gels. Acta Pathol Microbiol Scand 26, 507515

Radcliffe R, Heinze $T$ (1978) Isolation of plasminogen activator from human plasma by chromatography on Lysine-Sepharose. Arch Biochem Biophys 189, 185-194

Reimerdes EH, Halpaap J, Klostermeyer H (1981a) Milchproteinasen. 8. Vergleichende Charakterisierung von Plasmin aus Rinderblut mit einer Serinproteinase aus Kuhmilch. Milchwissenschaft 36, 19-22

Reimerdes EH, Halpaap J, Klostermeyer EH (1981b) Milchproteinasen. 10. Enzymkinetischer Vergleich bei Rinderplasmin mit zwei Milchproteinasen. Milchwissenschaft 36, 7379

de Rham O, Andrews AT (1982) The roles of native milk proteinase and its zymogen during proteolysis in normal bovine milk. $J$ Dairy Res 49, 577-585

Rollema HS, Visser S, Poll JK (1981) On the determination, purification and characterization of the alkaline proteinase from bovine milk. Neth Milk Dairy J 35, 396-399

Rollema HS, Visser S, Poll JK (1983) Spectrophotometric assay of plasmin and plasminogen in bovine milk. Milchwissenschaft 38, 214-217

Schaller J, Moser PW, Dann-Egger-Muller GAK, Rosselet SJ, Kampier U, Rickli EE (1985) Complete amino acid sequence of bovine plasminogen. Comparison with human plasminogen. Eur J Biochem 149, 267-278

Schmidt DG (1980) Colloïdal aspects of casein. Neth Milk Dairy J 34, 42-64

Slattery CW (1976) Casein micelle structure: an examination of models. J Dairy Sci $59,1547-$ 1556

Snoeren THM, Van Riel JAM (1979) Milk proteinase, its isolation and action on $\alpha_{\mathrm{s} 2}$ and $\beta$-casein. Milchwissenschaft 34, 528-531

Thorsen S (1975) Differences in binding to fibrin of native plasminogen and plasminogen 
modified by proteolytic degradation. Biochim Biophys Acta 393, 55-65

Walsh KA, Wilcox PE (1970) Serine Proteases. In: Methods in Enzymology. Proteolytic enzymes (Collowick SP, Kaplan NO, eds), Academic Press, 19, 31-41

Wiman B, Mellbraing G, Ranby M (1983) Plasminogen activator release during venous stasis and exercise as determined by a new specific assay. Clin Chim Acta 127, 279-288

Yamamoto J, Morita S, Okamoto V (1984) Clearance of modified plasminogen produced in the circulation after strenuous exercise. Thromb Res 36, 67-71

Yamamoto J, Okamoto U, Kojima S, Morita S, Fujii K (1982) A partially degraded form of human plasminogen in circulating blood. Clin Lab Hoematol 4, 117-130

Yamamoto J, Okamoto U, Moritas S, Kikui K, Fujii Y (1983) Production of the modified form of human plasminogen in the plasma activated by urokinase. Jap J Physiol 33, 469-484

Zittle CA (1965) Purification of protease in cow's milk. J Dairy Sci 48, 771 (abstract M40) 